\title{
Sexually transmitted infections among young patients at two general outpatient clinics in Southwest, Nigeria: Assessment of knowledge and risk factors
}

\author{
*Olorunsola Abimbola ${ }^{1}$, Adegoke Adedokun ${ }^{2}$.
}

\begin{abstract}
Background: Sexually transmitted infections are one of the health outcomes of risky sexual behaviour and they constitute health burdens among young population. The study assessed the knowledge, prevalence and contributing factors for sexually transmitted infections among young patients seen at two general outpatient clinics.
\end{abstract}

Method: The study adopted a cross-sectional design using a sample size of 370 unmarried young patients that were sexually active. Quantitative data was obtained using structured questionnaires and samples were taken to determine the causative organisms of sexually transmitted infections (STI). Analysis was done with SPSS, chi-square was used to test for association between STI and influencing factors and statistical level of significance was set at $5 \%$.

Results: General knowledge assessment showed $90.3 \%$ of the respondents knew STIs. Specific STI knowledge showed HIV/AIDS was known by $88.9 \%$ and chancroid by $14 \%$. About $26 \%$ of the respondent presented with itch, $22.1 \%$ with vaginal discharge and $5.9 \%$ with swelling on the perineum. Organisms identified were Candida albicans (47\%), Non-gonococcal urethritis (17.7\%) and the least was Herpes $1.96 \%$. Prevalence of STI was significantly associated with risky sexual behaviour $\left(\chi^{2}=8.437 ; \mathrm{p}=\right.$ $0.004)$, tertiary education $\left(\chi^{2}=5.330 ; \mathrm{p}=0.021\right)$ and poor family functioning $\left(\chi^{2}=5.507 ; \mathrm{p}=0.005\right)$.

Conclusion: Sexually transmitted infection was associated with risky sexual behaviour, education on behavioural change towards safe sexual practice is a tool that can help prevent the spread of the infection.

Key Words: Sexually transmitted infections, young patients, knowledge, risk factors, Nigeria.

\author{
*Corresponding Author \\ Olorunsola Abimbola.. \\ ORCID-NO: http://orcid.org/0000-0002-0091-1512 \\ Email:bimboolorunsola@gmail.com
}

\footnotetext{
${ }^{1}$ Department of Family Medicine, University College Hospital, Ibadan, Nigeria

${ }^{2}$ Department of Obstetrics and Gynaecology, University of Medical Sciences, Ondo, Nigeria.
} 


\title{
Infections sexuellement transmissibles chez les jeunes patients dans deux cliniques générales ambulatoires dans le sud-ouest du Nigéria : Évaluation des connaissances et des facteurs de risque
}

\author{
*Olorunsola Abimbola ${ }^{1}$, Adegoke Adedokun
}

\begin{abstract}
Résumé
Contexte général de l'étude : Les infections sexuellement transmissibles sont l'un des effets sur la santé des comportements sexuels à risque et elles constituent un fardeau pour la santé de la population jeune. L'étude a évalué les connaissances, la prévalence et les facteurs contributifs des infections sexuellement transmissibles chez les jeunes patients vus dans deux cliniques ambulatoires générales.
\end{abstract}

Méthode de l'étude : L'étude a adopté une conception transversale en utilisant un échantillon de 370 jeunes patients célibataires qui étaient sexuellement actifs. Des données quantitatives ont été obtenues à l'aide d'un questionnaire structuré et des échantillons ont été prélevés pour déterminer les organismes responsables des infections sexuellement transmissibles (IST). L'analyse a été effectuée avec SPSS, le test du chi carré a été utilisé pour tester l'association entre les IST et les facteurs d'influence et le niveau de signification statistique a été fixé à $5 \%$.

Résultat de l'étude: L'évaluation des connaissances générales a montré que 90,3\% des répondants connaissaient les IST. Les connaissances spécifiques sur les IST ont montré que le VIH/SIDAétait connu à $88,9 \%$ et le chancre mou à $14 \%$. Environ $26 \%$ des répondantes présentaient des démangeaisons, $22,1 \%$ des pertes vaginales et $5,9 \%$ un gonflement du périnée. Les organismes identifiés étaient le Candida albicans (47\%), l'urétrite non gonococcique $(17,7 \%)$ et le moins était l'herpès $1,96 \%$. La prévalence des IST était significativement associée aux comportements sexuels à risque $(\chi 2=8,437 ; \mathrm{p}=0,004)$, à l'enseignement supérieur $(\chi 2=5,330 ; p=0,021)$ et au mauvais fonctionnement de la famille $(\chi 2=5,507$; $\mathrm{p}=0,005)$.

Conclusion : Les infections sexuellement transmissibles étaient associées à des comportements sexuels à risque, l'éducation sur le changement de comportement vers une pratique sexuelle sans risque est un outil qui peut aider à prévenir la propagation de l'infection.

Mots-clés : Infections sexuellement transmissibles, jeunes patients, connaissances, facteurs de risque, Nigéria.

\author{
*Corresponding Author \\ Olorunsola Abimbola.. \\ ORCID-NO: http://orcid.org/0000-0002-0091-1512 \\ Email:bimboolorunsola@gmail.com \\ ${ }^{1}$ Department of Family Medicine, University College Hospital, Ibadan, Nigeria \\ ${ }^{2}$ Department of Obstetrics and Gynaecology, University of Medical Sciences, Ondo, Nigeria.
}




\section{INTRODUCTION}

Sexually transmitted infections are contagious heterogeneous diseases whose principal mode of transmission is sexual contact (1). Four million young people currently aged 10 19 years have sexually transmitted infections (STI) globally $(2,3,4)$. Common causative organisms include Chlamydia trichomatis, Nisseria gonorrhoea, Treponema pallidum, herpes and Candida albicans $(1,10)$. Prevailing organisms are similar across the world but with slight variation in different continents $(1,8,7,9,11)$. Studies in Nigeria isolated Candida albicans infection as the commonest organism $(10,12)$.

Most people are asymptomatic with only few percentages presenting with symptoms (1, $4,6,11,13-15)$. Some of the symptoms and signs are discharge from the genitalia (12-15), warty growths, painless or painful ulcers $(12,14-16)$, lower abdominal pain and urinary symptoms $(14,15)$. A constellation of symptoms form the basis for the syndromic approach used for management in primary care $(4,11,13)$.

Sexually transmitted infections account for morbidities and mortalities among African youths, the risk for HIV transmission is at least doubled by its presence $(1,17,18)$. Pelvic inflammatory diseases and other reproductive issues such as infertility and ectopic pregnancies complicate untreated chlamydia and gonorrhoea in young females $(1,4,5,6,15)$. Among males, gonorrorrhea and chlamydia can lead to infertility following epididymitis, while urinary tract symptoms can also complicate urethral strictures $(2,4)$.

STI also accounts for significant loss of healthy life years among young population worldwide $(2,8-9,15)$. Higher incidence of STI is observed among young people because of sexual experimentation and these sexual activities are usually risky as characterised by early intercourse, having multiple partners and failure to use condoms $(1,8,12,19)$. The odds for STI increases with sexual debut at early age of thirteen years compared to later sexual exposure (20-22).

Females are particularly vulnerable than male counterparts due to biological, cultural, and socioeconomic conditions. ${ }^{7,13,18}$ Cultural norms of male dominance and older men's preference for younger females contribute to females' vulnerability (21-22).

Involvement in unsafe sexual practice sometimes occurs in the presence of poverty. While fending for needs, young individuals engage in commercial sex which increases the risk for being infected (22-23).

Likewise, family functioning as underscored by bond among members, parental education, and parent health related risk behaviours influences sexual practices of their progenies (25-27). The behaviour of children growing up at homes are generally influenced by the disposition of family interaction.

The prevalence of sexually transmitted infections among young population has not witnessed a significant reduction, continuous work on circumstances of infectivity among them is essential in driving prevention. Hence, this study assessed knowledge, prevalence and factors related with sexually transmitted infections among young patients presenting at General Outpatient Clinics in South - West, Nigeria.

\section{MATERIALS AND METHODS Study population and Design}

This descriptive cross-sectional study was carried out among 370 sexually active unmarried young patients who presented at two General Outpatient Clinics. The two centres were selected based on simple random sampling technique from public secondary hospitals in Ibadan. The study included unmarried sexually active respondents who were between 15 and 24 years, selected by convenient sampling from population of young patients at the two clinics.

\section{Data collection procedures}

A structured pretested interviewer administered questionnaires were used to obtain information which related to study objectives after obtaining informed consent while ensuring utmost privacy. Questions focused on sociodemographic characteristics, sexual behaviour, family functioning, knowledge and symptoms of STI. Data on knowledge of STI was gathered by first asking a general question on awareness of any disease being transmitted through sexual intercourse then knowledge of specific infection was assessed through identification of different types of STI using a Yes or No answer respectively. Family functioning was assessed using the Family Environmental Scale on quality of family relationship. ${ }^{28}$ Risky sexual behaviours was assessed by the presence of early intercourse, multiple sexual partners, inconsistent use of condom or sex in exchange for money or favour. STI was assessed clinically and with laboratory investigation conducted on sample taken from respondents with vaginal discharge during the 
study. None of the male participants had penile discharge.

\section{Specimen Collection}

High vaginal and endocervical swabs samples were taken from respondents with vaginal discharge by observing aseptic procedure and through the use of sterile speculum. Specimens were inoculated into the Stuarts Transport medium at the collection site. The swabs were sent for microscopy culture and sensitivity test at the laboratory within 1 hour of collection where samples were cultured into different culture media in the laboratory. At the end of the period of incubation, all the organisms grown were examined so as to isolate and confirm the causative agents.

Benefits: All respondents were counselled on safe sexual practice, and the need for HIV testing. Respondents with features of STIs had drugs prescribed to them.

\section{Data Analysis}

Data entry and analysis were done using SPSS, the descriptive data were presented with tables and charts using frequencies, proportions and means. Chi square was used to test association between STI and its influencing factors. The level of significance was set at $5 \%$.

Ethical Consideration: Ethical approval for study was granted by both U.I/U.C.H Ethical Committee and Oyo State Ministry of Health.

\section{RESULTS}

\section{Basic Characteristics of Respondents.}

Table 1 shows the sociodemographic characteristics of the respondents with higher percentage $85.1 \%$ being aged $20-24$ years and a mean age of $21.86+2-112$ years. Females accounted for $63.8 \%$ and males $36.2 \%$ of the respondents. Majority (61.9\%) had tertiary education while primary education accounted for the lowest proportion (3.0\%). Half of the respondents were from lower social family background.

\section{Knowledge of Sexually Transmitted Infections}

Table 2 shows Knowledge of Sexually Transmitted Infections among Respondents. Three hundred and thirty-four (90.3\%) knew infections were transmissible through sexual intercourse on general STI knowledge assessment. Assessment of knowledge of specific STI type showed most respondents 334(88.9\%) knew about HIV/AIDS, next was gonorrhoea by 267(72.7\%), while the least number 52 (14.1\%) accounted for knowledge on chancroid.

\section{Symptoms of Sexually Transmitted Infections among Respondents}

Figure 1 shows the symptoms of STI reported by respondents. A little above a quarter $25.9 \%$ of the respondents presented with itch, followed by vaginal discharge and lower abdomen pain which were $22.1 \%$. and $14.4 \%$ respectively. The least reported symptom was swelling in the perineum with a frequency of $5.9 \%$.

\section{Distribution of Sexually Transmitted Infections among Respondents}

Figure 2 shows Candida albicans was the commonest causative organism of STIs among the respondents accounting for $47 \%$, followed by Non gonococcal urethritis $17.7 \%$. Both herpes simplex and viral warts accounted for $1.96 \%$ each among the respondents. Epithelial cells were observed in $9.8 \%$ of cultured specimens without any cultured organism.

\section{Prevalence and Associated Factors with STI among Respondents.}

The prevalence of sexually transmitted infections among the respondents was $13.8 \%$. Analysis of factors showed that STI was significantly higher among respondents that practiced risky sex with a prevalence of $17.5 \%$ $(\chi 2=8.438, \quad p=0.004)$. Non- significant association was found on effect of gender and age on STI although a higher proportion of females $14.8 \%$ had STI $\left(\chi^{2}=0.962, \mathrm{p}=0.327\right)$ and more of respondents aged $20-24$ years $14.9 \%$ had STI $\left(\chi^{2}\right.$ $=2.305, \mathrm{p}=0.143)$. A significantly higher proportion of STI (17.0\%) was observed among respondents with tertiary level of education $\left(\chi^{2}=\right.$ $3.638, \mathrm{p}=0.021)$. Respondents from the middle social class had the highest proportion of STI which was $17.5 \%$ compared to the other classes but the difference was not significant $\left(\chi^{2}=2.190\right.$, $p=0.135)$. Respondents from families with poor functioning had a significantly higher proportion of STI 16\% compared with good functioning with $3.2 \%$ at $\mathrm{p}=0.005$.

\section{DISCUSSION}

Assessment of general knowledge of STI among participants in this study showed a large proportion of the respondents were aware that diseases could be transmitted through sexual intercourse. Although Mwambete in Tanzania 
(29) and Dongurum (30) in Nigeria reported slightly higher knowledge of $98 \%$ among the studied youths. Further analysis on specific infection type showed participants had poor knowledge except for knowledge of HIV which was the highest among respondents. This observation was consistent with the findings by Zeeb in a systematic review among youths in Europe where awareness of HIV as a type of STI was $88 \%(3)$.

The prevalence of Sexually transmitted infections found in this study was lower than the proportion of $47 \%$ reported by Adegun, however both studies observed genital itch as the commonest presentation (34). Candida albicans was the highest isolated organism in this study, similar to report by two independent studies $(10,32)$. Gonorrhoea was also cultured although not as much as was reported by a meta analysis study where it was the most cultured organism (33). Failure to grow organisms in some culture media in this study may be suggestive of abuse of broad spectrum antibiotics which is a common practice in this environment.

This study found that risky sexual practice as a factor accounted for a greater prevalence of sexually transmitted infections and its proportion was higher compared to those who practiced safe sex among the respondents. There was an incongruence trend between the level of knowledge of STIs and unsafe sexual behaviour among the studied young people. This probably illustrates a gap in the understanding of the connection between sexual behaviour and sexually transmitted infections among adolescents in this country. Although, the observed influence of unsafe sexual practice on sexual infections was in tandem with other studies $(3,22,24,32)$. More females were infected and this corroborates the fact that the female gender predisposes adolescents to contacting sexual infection $(9,17,20)$. Higher prevalence of STIs was observed among the older youths, possibly from involvement in risky sex over a longer period than the younger ones $(4,12,33)$.

The respondents with tertiary education had a higher percentage of STDs than those with lower level of education similar to a report by Nwadike et al (10). This finding appeared to be in enigma with the academic level, it further confirms deficiency in sexual education even among educated young people. A different consideration for the higher proportion of STIs among them reflected possibility of clearer knowledge on symptoms of STIs leading to access of medical care as at the time of this study.
Finding of more STIs among participants from middle social class agreed with a study in Uganda where it was found that individuals in this economic group had multiple sexual partners and hence higher risk for sexually related diseases (4).

A positive family relationship cannot be underestimated as a primary factor that protects youths from engaging in unsafe sexual behaviour. Association of poor family functioning with sexually transmitted infection is a reflection of interaction between poor family relationship and unsafe sexual choices $(18,25,26,30)$.

\section{CONCLUSION}

The prevalence of sexually transmitted infections among unmarried young patients in this study was associated with factors such as risky sexual practice, poor family functioning and level of education. Knowledge of specific sexually transmitted infections apart from HIV was poor among the respondents. More comprehensive age appropriate sexual education and advocacy on sexual behavioural change must be promoted as keys to primary prevention of sexually transmitted infections.

Conflict of Interest: Authors declared no conflict of interest;

\section{REFERENCES}

1 Centres for Disease Control and Prevention. STDs in Adolescents and Young Adults. Sexually Transmitted Diseases Surveillance. 2009. assessed $16^{\text {th }}$ June 2011. Available from: http://www.cdc.gov/stdconference/2010

2 World Health Organization. Global Health Risks: Mortality and burden of disease attributable to selected major risks. WHO Geneva.2009. Accessed $9^{\text {th }}$ march 2011 available from www.who.int/healthinfo/global_burden/globalhe althrisks report..

3 Centre for Disease Control and Prevention. Youth risk behaviour surveillance - United States. MWR 2010; 59(5):1-142

4 World Health Organization- Report on Global Sexually Transmitted Infection Surveillance. $\mathrm{W}$ H O $\quad \mathrm{F}$ a c t $\mathrm{S}$ h e e t. $\begin{array}{lllll}2 & 0 & 1 & 8\end{array}$. https/www.who.int.sti.surv.

5 Anguzu G, Musaazi J, Kasirye. Relationship between socioeconomic status and risk of sexually transmitted infections in Uganda: Multilvevel analysis of a nationally representative survey. Int Journal of STD and AIDS.2018;1-8

6 Centres for Disease Control and Prevention. Sexually Transmitted Diseases in Adolescents and Young Adults. Sexually Transmitted Disease Surveillance. 2011. Accessed December 12, 2011. Available from:www.cdc.gov/std/htm. 
7 World Health Organisation. Global strategy for the prevention and control of sexually transmitted infections: 2006-2015 Breaking the chain of Transmission. WHO. Geneva. 2007.

8 Assessment of the management of sexually transmitted Diseases in Ghana. Ministry of Health. Health Research unit Ghana. 2000. Accessed august 122010.

9 Cheung KK, Montgomery D, Benjamins LJ. Prevalence of Sexually Transmitted Infections Among Adolescents Entering Child Protective Services. J Pediatr Adolesc Gynecol. 2015; (5): 324-326.

10 Nwadike VU, Olusanya O, Anaedobe GC, Kalu I, Ojide KC. Patterns of sexually transmitted infections in patients presenting in special treatment clinic in Ibadan south western Nigeria . The Pan African Medical Journal. 2015; $21: 222$.

11 Choudhry S, Ramachandran VG, Das S, Bhattacharya SN, Mogha NS. Pattern of sexually transmitted infections and performance of syndromic management against etiological diagnosis in patients attending the sexually transmitted infection clinic of a tertiary care hospital.Indian J Sex Transm Dis. 2010; 31(2): 104-108.

12 Olasode OA. Sexual behaviour in adolescent and young people attending sexually transmitted clinic in Ile Ife. Indian Journal of STD and AIDS. 2

13 Cheng Y, Paintsil, Ghebremichael M. Syndromic versus Laboratory Diagnosis of Sexually Transmitted Infections in Men in Moshi District of Tanzania.Aids Res and Trt .https/doi org/10.1155/20207607834.

14 Grosskurth H, Mwijarubi E, Todd J, Rwakatare M, Orroth K, MayaudP,et al. Operational performance of an STD control programme in Mwanza Region, Tanzania. Sex Transm Inf. 2000;76:426-36.

15 Agustine J. Adolescents and sexually transmitted infections. Advocates for Youth.2010. Accessed May $7^{\text {th }} 2011$. Available from : www.advocatesforyouth.org/456.

16 Zin NM, Ishak I, Manoharan K. Knowledge, Attitude and Practice towards sexually transmitted diseases amongst the inmates of women shelters homes at klang valley. BMCPubl Hlth. 2019; 19.

17 Lamptey PR, Johnson JL, Khan M. The global challenge of HIV and AIDS. Population Reference Beareau Publication. 2006; 61(1):124.

18 DiClemente RJ, Salazar LF, Crosby RA. A review of STD/HIV preventive intervention for adolescents: sustaining effects using an ecological approach. 2006; 32, (8): 888-906.

19 Wildsmith E, Schelar E, Peterson K, Manlove J. Sexually transmitted diseases among young adults: prevalence, perceived risk, and risk-taking behaviours. 2010:1-7. Accessed June 102011. Available from: $w w w$. child trend.org.
20 Pettifor AE, Stratena AV, Dunbara MS, Shiboskia SC, Padiana NS. Early age of first sex: a risk factor for HIV infection among women in Zimbabwe. Lippincott Williams \& Wilkins. 2004; 18:1435-42.

21 Fatusi AO. Adolescent sexual and reproductive health needs in Nigeria: shaping a pragmatic and effective response. J of Comm and Pri Health Care. 2005; (1): 1-6.

22 Iwuagwu SC, Ajuwon AJ, Olaseha IO. Sexual behaviour and negotiation of the male condom by female students of the University of Ibadan, Nigeria. Journal Obstetrics Gynaecology. 2000; 20 (5):507-13.

23 Guttmacher Institute. Facts on American teens' sexual and reproductive Health, 2008 accessed D e c e mber 122010 . Available http://www.guttmacher.org/pubs/USTPtrends.

24 Urassa W, Moshiro C, Chalamilla G, Mhalu F, Sandstrom E. Risky sexual practices among youth attending a sexually transmitted infection clinic in Dar es Salaam, Tanzania. BMC Infect Dis. 2008; 8: 159 .

25 Adejumo GO. Impact of family type on involvement of adolescents in pre-marital sex. International Journal of Psychology and Counselling. 2011;3(1):15-19.

26 Kirby D:IN: O'Donnell L, Rene'e W, Kim D, Varzi J, Mynth A, Jesse M, et al. Saving Sex for Later: developing apparent child communication intervention to delay sexual initiation among young adolescents. Journal of Sex education. 2007;7(2): 107-125.

27 Bray JH, Campbell TL. The family influence on health. In: Saunders E. Rakel textbook of family Medicine. $7^{\text {th }}$ Edition An Imprint of Elsevier ; 2007; chap 3: page 14-17.

28 Moos H. Family Environment Scale. Family Environment Scale Manual and Sampler Set: Development, Applications and Research: $4^{\mathrm{TH}}$ edition: 2009: 31-34.

29 Mwambete KD, Mtaturu Z. Knowledge of sexually transmitted diseases among secondary school students in Dar es Salaam, Tanzania. Afr Health Sci. 2006; 6(3): 165-69.

30 Dongurum CK, Marcus ND. Sex behaviour of adolescents in Qua'an-pan local government area, Plateau State. Nig J of Soc Reseac. 2009;1(5):8092

31 Samkange-Zeeb FN, Spallek L, Zeeb H. Awareness and knowledge of sexually transmitted diseases (STDs) among school-going adolescents in Europe: a systematic review of published literature. BMC Public Health. 2011;11:727.

32 Okonko IO, Akinpelu AO, Okerentugba PO. Prevalence of Sexually Transmitted Infections (STIs) among attendees of AFRH Centre in Ibadan, Southwestern Nigeria. Middle-East Journal of Scientific Research. 2012;11(1): 24-31.

33 Torone EA, Morrison CS,Chen PL, Kwok C,Francia SC,Hayes $\mathrm{Rj}$ et al. Prevalence of. Sexually transmitted infections and bacterial 
vaginosis among women in sub-Saharan africs: an individual participant data meta-analysis of 18 HIV prevention studies. Plos Med .2018:15(2)

34 Adegun PT, Anu EO. Prevalence and Health Care Seeking Behaviour for Sexually transmitted infectionsamong in- school adolescents in AdoEkiti, South Western Nigeria. Int of Adol Med. https/doi/10.1515/2016.

How to cite this article:

Olorunsola Abimbola, Adegoke Adedokun. Sexually transmitted infections among young patients at two general outpatient clinics in Southwest, Nigeria: Assessment of knowledge and risk factors. Research Journal of Health Sciences, 2021, 9(4):368-377 
Table 1: Basic Characteristics of Respondents

\begin{tabular}{lll}
\hline Variable & $\begin{array}{l}\text { Frequency } \\
(\mathbf{n = 3 7 0 )}\end{array}$ & $\begin{array}{l}\text { Percentage } \\
(\mathbf{\%})\end{array}$ \\
\hline Age & & \\
$15-19$ & 55 & 14.9 \\
$20-24$ & 315 & 85.1 \\
& & \\
Sex & & \\
Male & 134 & 36.2 \\
Female & 236 & 63.8 \\
& & \\
Level of education & & \\
Primary & 11 & 3.0 \\
Secondary & 130 & 35.1 \\
Tertiary & 229 & 61.9 \\
& & \\
Social class & & \\
Upper & 81 & 21.9 \\
Middle & 103 & 27.8 \\
Lower & 186 & 50.3 \\
\hline
\end{tabular}

Table 2: Assessment of Knowledge of STI among Respondents.

\begin{tabular}{lll}
\hline Knowledge Assessment & $\begin{array}{l}\text { Yes } \\
\text { N(\%) }\end{array}$ & $\begin{array}{l}\text { No } \\
\text { N(\%) }\end{array}$ \\
\hline General & $334(90.3)$ & $36(9.7)$ \\
Specific Infection Type & & \\
HIV/AIDS & $329(88.9)$ & $41(11.1)$ \\
Gonorrhea & $267(72.2)$ & $103(27.8)$ \\
Syhphilis & $185(50)$ & $185(50)$ \\
Viral Wart & $110(29.7)$ & $260(70.3)$ \\
chancroid & $52(14.1)$ & $318(85.9)$ \\
\hline
\end{tabular}




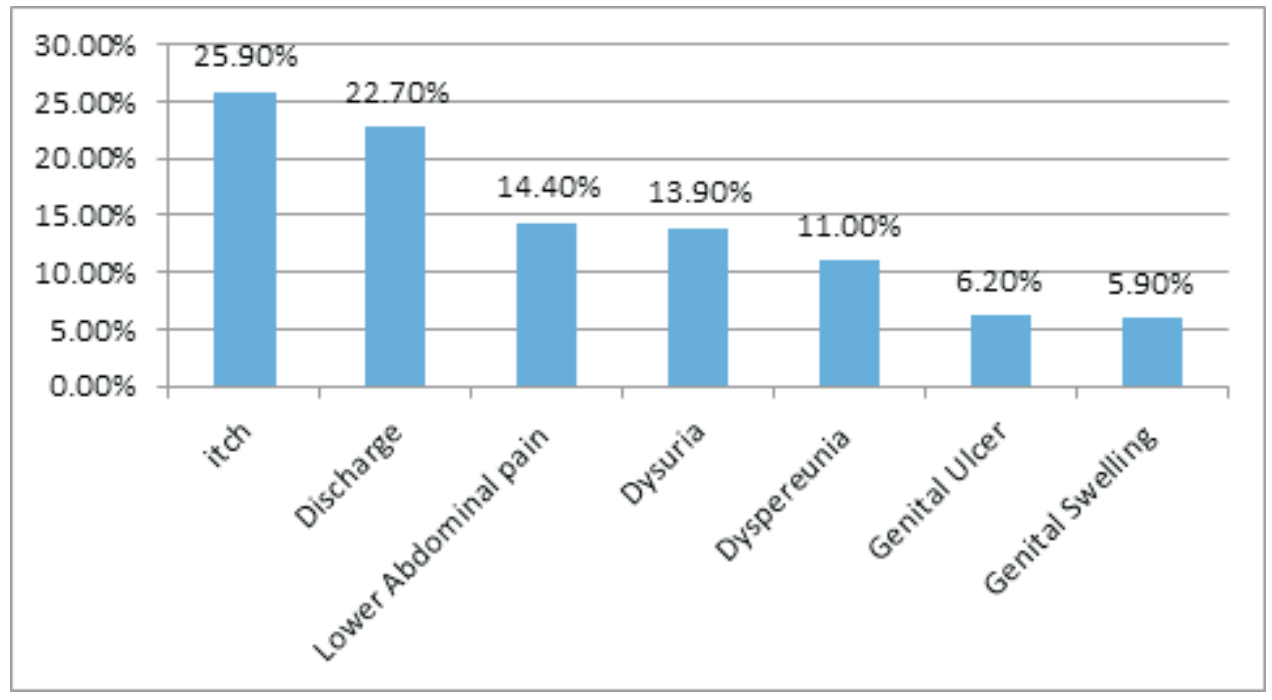

Figure 1: Pattern of Symptoms of STIs among Respondents.

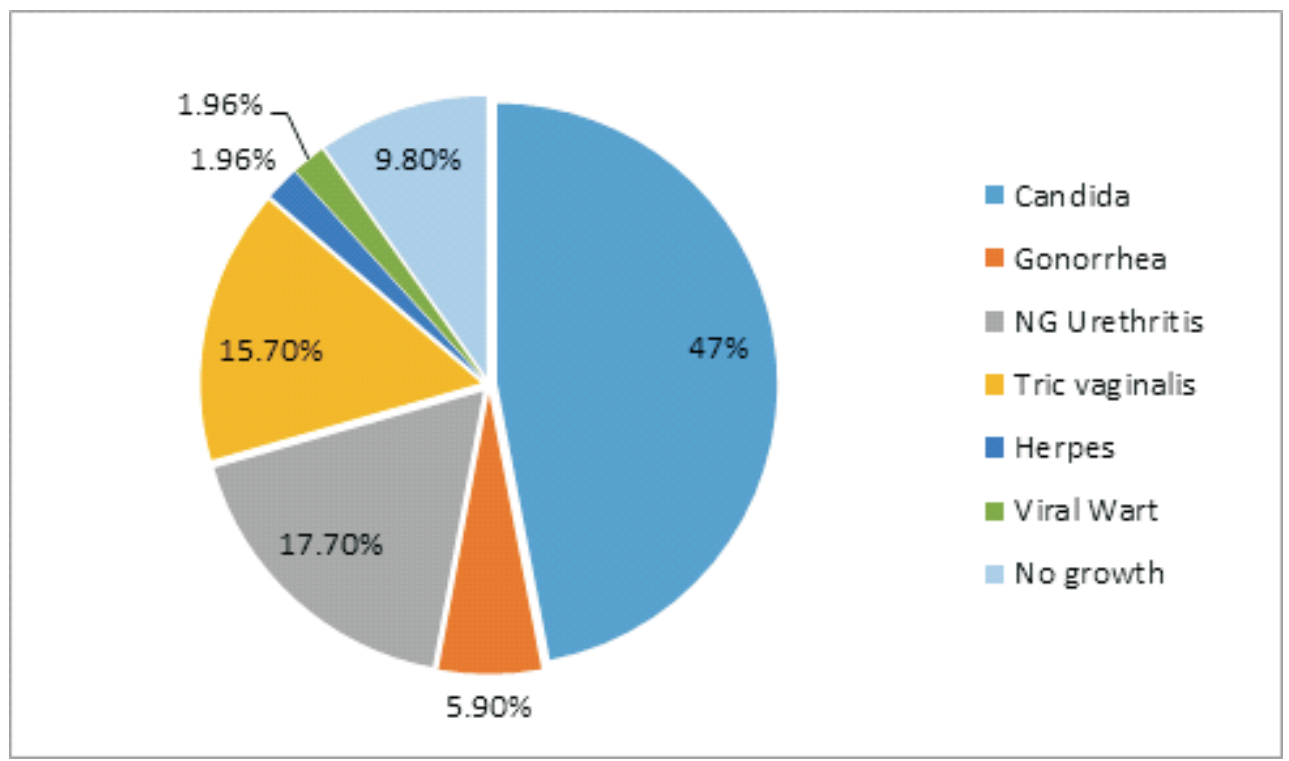

Figure 2: Causative Organisms of STIs among Respondents. 
TABLE 3: Prevalence of STI and associated factors among respondents.

\begin{tabular}{|c|c|c|c|c|c|}
\hline Prevalence & Frequency (N) & \multicolumn{2}{|c|}{ Percentages (\%) } & \multirow[b]{4}{*}{$\chi^{2}$} & \multirow[b]{4}{*}{ p value } \\
\hline Yes & 51 & 13.8 & & & \\
\hline No & 319 & 86.2 & & & \\
\hline & & \multicolumn{2}{|c|}{ STI } & & \\
\hline Variable & Level & $\begin{array}{l}\text { YES } \\
\mathrm{n}(\%)\end{array}$ & $\begin{array}{l}\mathrm{NO} \\
\mathrm{n}(\%)\end{array}$ & & \\
\hline Sexual Pract & & & & & \\
\hline & $\begin{array}{l}\text { Safe } \\
\text { Risky }\end{array}$ & $\begin{array}{l}8(6.5) \\
43(17.5)\end{array}$ & $\begin{array}{l}116(93.5) \\
203(82.5)\end{array}$ & 8.438 & 0.004 \\
\hline Sex & & & & & \\
\hline & $\begin{array}{l}\text { Male } \\
\text { Female }\end{array}$ & $\begin{array}{l}16(11.9) \\
35(14.8)\end{array}$ & $\begin{array}{l}118(88.1) \\
201(85.2)\end{array}$ & 0.601 & 0.531 \\
\hline Age group & $\begin{array}{l}15-19 \\
20-24\end{array}$ & $\begin{array}{l}4(7.3) \\
47(14.9)\end{array}$ & $\begin{array}{l}51(92.7) \\
268(85.1)\end{array}$ & 2.305 & 0.143 \\
\hline Level of Edu & $\begin{array}{l}\text { Non-Tertiary } \\
\text { Tertiary }\end{array}$ & $\begin{array}{l}12(8.5) \\
39(17.0)\end{array}$ & $\begin{array}{l}129(91.5) \\
190(83.0)\end{array}$ & 5.330 & 0.021 \\
\hline Social Class & $\begin{array}{l}\text { Lower } \\
\text { Middle } \\
\text { Upper }\end{array}$ & $\begin{array}{l}19(10.2) \\
18(17.5) \\
14(17.3)\end{array}$ & $\begin{array}{l}167(89.8) \\
85(82.5) \\
67(82.7)\end{array}$ & 4.010 & 0.135 \\
\hline $\begin{array}{l}\text { Family } \\
\text { Functioning }\end{array}$ & $\begin{array}{l}\text { Poor } \\
\text { Good }\end{array}$ & $\begin{array}{l}49(16.0) \\
2(3.2)\end{array}$ & $\begin{array}{l}258(84.0) \\
61(96.8)\end{array}$ & 7.191 & 0.005 \\
\hline
\end{tabular}

